\title{
MOLLUSC DIVERSITY AT PULICAT LAGOON (INDIA)
}

$$
\text { Ravichandran RAMANIBAI * and Sivalingam GOVINDAN ** }
$$

* University of Madras, Department of Zoology, Guindy Campus, Sardar Patel Road, Chennai, Tamil Nadu, India, IN-600025, rramani8@hotmail.com, rramani8@unom.ac.in

** University of Madras, Department of Zoology, Guindy Campus, Sardar Patel Road, Chennai, Tamil Nadu, India, IN-600025, s.govindan88@gmail.com

DOI: 10.1515/trser-2018-0003

KEYWORDS: Diversity, bivalve, gastropod, ecosystem, Thiruvallur District, India.

\section{ABSTRACT}

During our routine ecological survey conducted at Pulicat Lagoon, the most diverse class Gastropods comprised of 26 families with 34 species and Bivalvia with 13 families and 17 species were recorded. The most abundant molluscs species was Crassostrea madrasensis, captured between October 2013 - September 2015. Quite a good number of molluscs were washed ashore. The economic value of the shells in the field of cosmetics was raised high recently. Both in terms of aquaculture and market value the attention should be diverted towards their conservation. With few exceptions, the majority of these molluscs were ornamental.

RÉSUMÉ: La diversite des mollusques du lagon de Pulicat (India).

Durant notre étude écologique de routine effectuée dans le lagon de Pulicat, la classe la plus diversifiés des Gastropodes contient 34 espèces et 26 familles suivies par les Bivalves avec 17 espèces et 13 familles. Dans les prises d'Octobre 2013 - Septembre 2015, l'espèce la plus abondante a été la Crassostrea madrasensis. Un grand nombre de mollusques s'échouent sur les rives et récemment. La valeur économique des coquillages a augmenté de manière significative. En ce qui concerne l'aquaculture ainsi que la valeur de marché, l'attention devrait se porter plus vers leur conservation. A quelques exceptions près, la grande majorité sont des mollusques ornementaux.

REZUMAT: Diversitatea moluștelor din Laguna Pulicat (India).

În cadrul studiului nostru ecologic de rutină, efectuat în laguna Pulicat, s-au înregistrat 34 specii din 26 familii aparținând clasei Gastropoda, cea mai bine reprezentată, și 17 specii din 13 familii aparținând clasei Bivalvia. În capturile din Octombrie 2013 - Septembrie 2015, specia cea mai abundentă a fost Crassostrea madrasensis. Un mare număr de moluște au fost aduse pe țărm de valuri. Valoarea economică a cochiliilor cu aplicaţii cosmetice a crescut recent. Atât în termeni de acvacultură cât și de valoare de piață, atenția trebuie reorientată către conservarea acestor specii. Cu câteva excepții, majoritatea acestor moluște sunt ornamentale. 


\section{INTRODUCTION}

The role of molluscs proved to be beneficial both cost-effectively as well as medicinally in the recent past (Wosu, 2003). They are important to humans as a source of food, jewellery, tools and even pets. Molluscs play a significant role in public and veterinary health (Supian and Ikhwanuddin, 2002). Biomphalaria glabratus caused with schistosomiasis (Richards, 1970).

In India 3,271 molluscs belong to 220 families and 591 genera, of which 1,900 are gastropods, 1,100 are bivalves (Venkatraman and Venkataraman, 2012). The studies on Indian molluscs were initiated by the Asiatic Society of Bengal and the Indian museum, Calcutta (Venkataraman and Wafar, 2005). Subba Rao and Dey (2000) reported 3,370 species of marine molluscs in India, out of which 1,282 species were from Andaman and Nicobar Islands. Subba Rao (2003) contributed in the field of mollusc's faunal diversity from Indian coastal regions.

Pulicat Lake is one of the most productive ecosystems in India. Chacko et al. (1953) gave the first exhaustive account of the biodiversity of the Pulicat Lake and it has been considered as a classical benchmark in the field biodiversity of the Pulicat Lake (Sanjeeva Raj, 2003, 2006). In previous studies, we have reported the Avifaunal diversity at Pulicat Lagoon (Govindan et al., 2015). The distribution of the mollusc's fauna in the Pulicat Lagoon has been reported by Thangavelu and Sanjeeva Raj (1985). They have also described the extensive mining of molluscs shells (Thangavelu and Sanjeeva Raj, 1985) in the northern regions of the Pulicat Lagoon. In order to update already existing data on mollusc's diversity we conducted a two year survey, which covered the entire area of Pulicat Lagoon.

\section{MATERIAL AND METHODS}

Pulicat Lagoon is the second largest brackish water, lying partly in Tamil Nadu and Andhra Pradesh. In Tamil Nadu, the Pulicat Lagoon is located in Pulicat Vvillage in Thiruvallur District. It is connected with the Bay of Bengal through a deep opening of about $0.8 \mathrm{~km}$ width situated about $1.6 \mathrm{~km}$ north of the Pulicat light house. Five sampling stations, namely Barmouth (S1), Kunankuppam (S2), Light house kuppam (S3), Sattankuppam (S4) and Jameelabad (S5) (Fig. 1) were selected at Pulicat Lagoon.

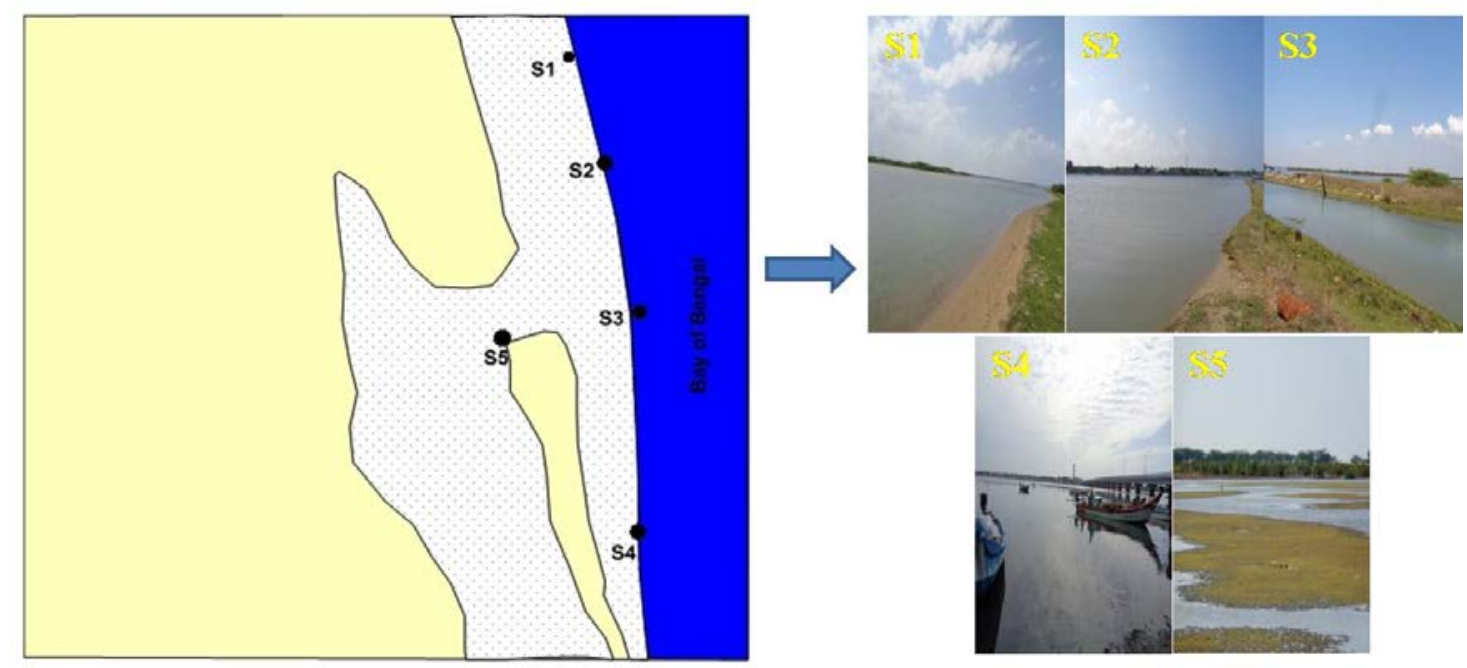

Figure 1: Sampling locations in Pulicat Lagoon. 
The mollusc's shells were collected by hand picking, scraping method and through laboratory. The shells were washed with water to remove adhering debris without damaging and then dried. The collected molluscs were identified with morphological characters. The gastropods were mainly identified based on the spire length and shape, mouth opening, opercular, umbilicus, colour and ornamentation and bivalves on the hinge, interlocking dentition, with referred to elsewhere Richards (1970), Vannucci (2002), Subba Rao (2003), Ramakrishna and Dey (2010), Venkatraman and Venkatraman (2012).

The specific shell characters like spire shape and length, opercular, umbilicus, mouth cavity, colour and ornamentation, were used primarily for the recognition of studied gastropods. The studied bivalves were recognized principally based on the shell morphology and the two valves. The external surface may be striated and the two valves held together by a ligament and a scar on the hinge.

1. The Shannon-Wiener diversity index, Simpson's index and Margalef's richness index were calculated for estimating mollusc's diversity. The data were subjected to diversity indices and cluster analysis using PAST Software, Margalef index (Margalef, 1958).

Margalef's index was used as a simple measure of species richness

Margalef's index $=(\mathrm{S}-1) / \mathrm{In} \mathrm{N}$

$\mathrm{S}=$ total number of species

$\mathrm{N}=$ total number of individuals in the sample

In = natural logarithm (Margalef, 1958)

2. Shannon Diversity Index "H"

$\mathrm{H}=-\Sigma[(\mathrm{ni} / \mathrm{N}) \times(\operatorname{lnni} / \mathrm{N})]$

H: Shannon Diversity Index

ni: Individuals number associated to i species

$\mathrm{N}$ : Individuals total number (Magurran, 2004)

3. Simpson Diversity Index " $D$ "

Simpson's index of dominance:

$\mathrm{D}=\Sigma$ ni $($ ni- 1$) / \mathrm{N}(\mathrm{N}-1)$

Where, $\mathrm{ni}=$ the total number of individuals of a particular species.

$\mathrm{N}=$ the total number of individuals of all species (Magurran, 2003)

4. Pielou Evenness Index “J” (Pielou, 1966)

$\mathrm{J}=\mathrm{H} / \mathrm{Hmax} \mathrm{J}$ : Pielou evenness index H

The observed value of Shannon Shannon index Hmax: $\ln S$

S: Total number of species (Pielou, 1966)

\section{RESULTS AND DISCUSSION}

Gastropods and bivalves are the two major classes of phylum mollusc contributed by 39 families belonging to 51 species. The most diverse class: Gastropod has 26 families belonging to 29 genera, 34 species (Fig. 2; Tab. 1) and Bivalve included 13 families, 15 genera and 17 species (Fig. 3; Tab. 2). 39 family, 51 species were located at Barmouth (S1), 39 family, 50 species were located at Kunankuppam (S2), 29 family 35 species were located at Light house kuppam (S3), 27 family 23 species were located at Sattankuppam (S4) and at Jameelabad (S5) 25 family, 30 species were located (Tab. 1). The Conidae were found to be the dominant family in Pulicat Lagoon. 
Gastropods and bivalves are generally benthic organisms and they are frequently used as bio indicators of aquatic health. A similar study was conducted at a few localities from the Raigad District the Maharashtra West Coast of India. Nearby 22\% bivalves and 78\% gastropods were recorded throughout October 2010 to September 2011 (Khade and Mane, 2012). In total 55 species of molluscs representing 13 orders, 30 families and 39 genera were recorded from the mangroves of Uran, Maharashtra (Pawar, 2012). An analogous study was carried out at Dadar and Juhu beach in Mumbai that revealed the availability of 19 genera and 14 families collectively on both coast lines. Most number of Bivalves belonged to the Cardidae while maximum Gastropods were from Trochidae family (Joshi et al., 2013). The study revealed that there is a good diversity of molluscs.

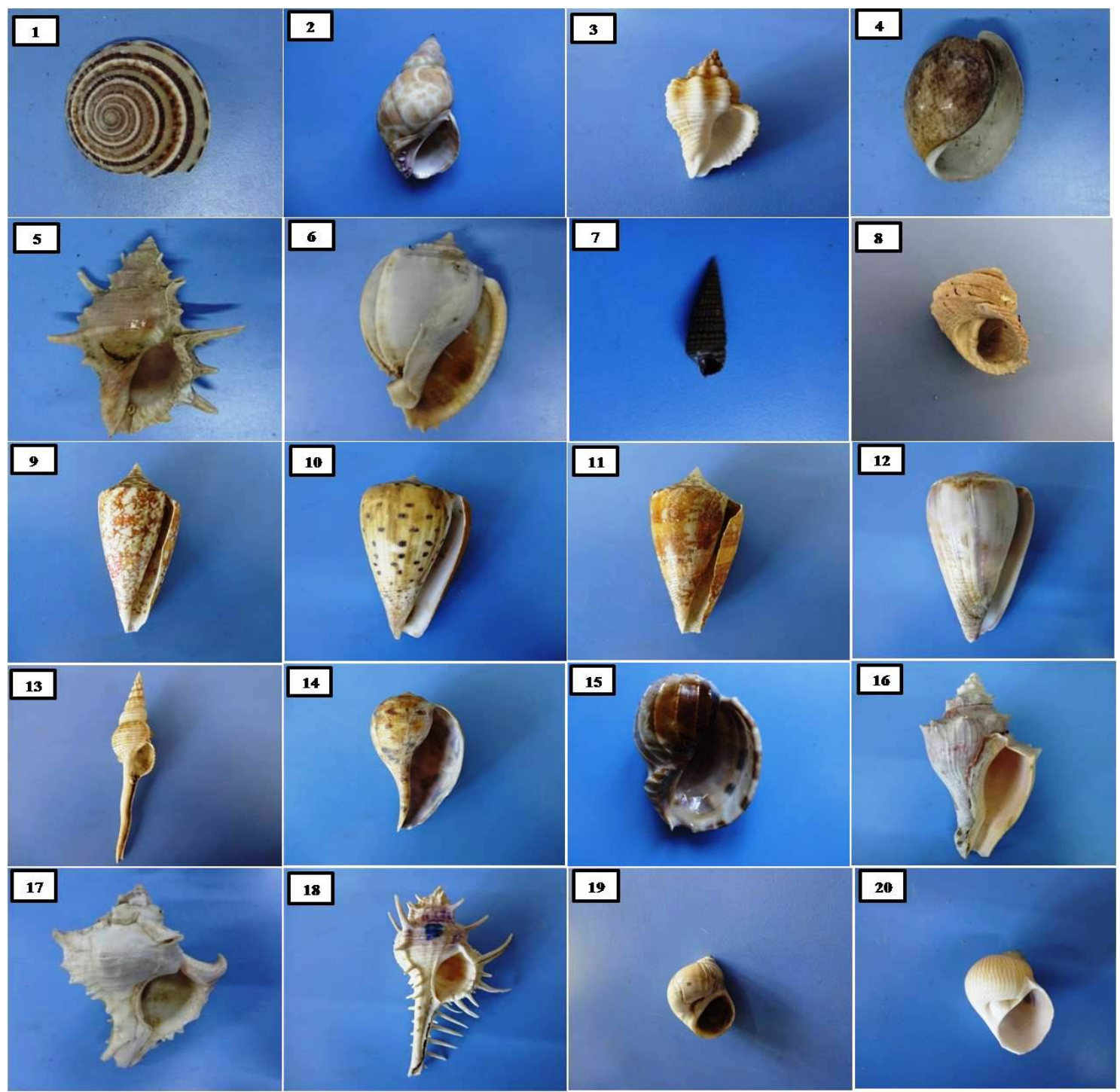

Figure 2: Distribution of Gastropods in Pulicat Lagoon. 


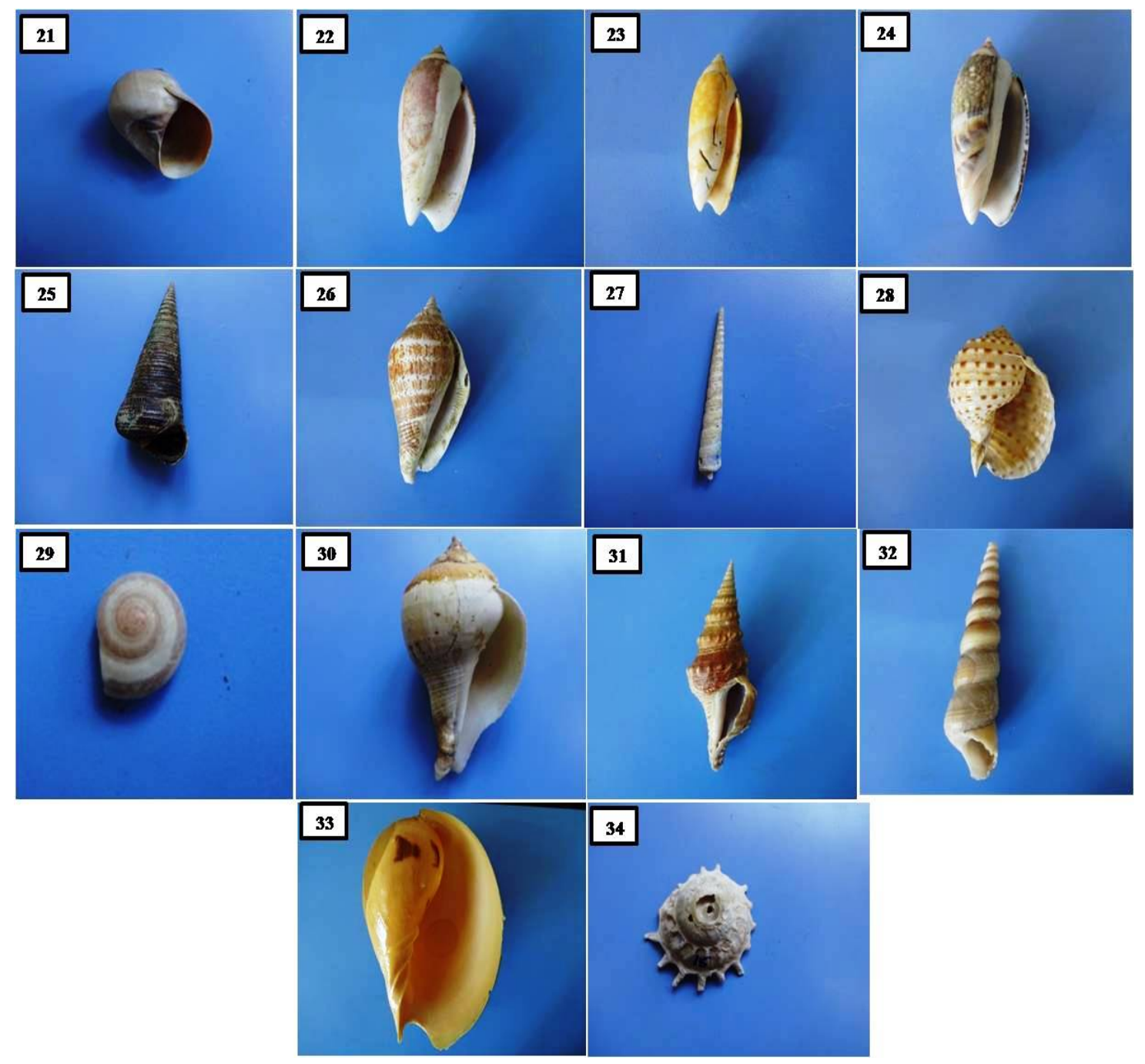

Figure 3: Distribution of Gastropods in Pulicat Lagoon. 
Table 1: List of gastropod identified from Pulicat Lagoon.

\begin{tabular}{|c|c|c|c|c|c|c|}
\hline Family & Name of the species & S1 & S2 & S3 & S4 & S5 \\
\hline 1. Architectonicidae & Architectonica perspectiva & + & + & + & - & - \\
\hline 2. $\quad$ Babyloniidae & Babylonia zeylanica & + & + & + & - & - \\
\hline 3. Buccinidae & Cantharus tranquebaricus & + & + & + & - & + \\
\hline 4. $\quad$ Bullidae & Bulla ampulla & + & + & - & - & - \\
\hline 5. Bursidae & Bufonaria echinata & + & + & - & - & - \\
\hline 6. Cassidae & Phalium glaucum & + & + & + & + & + \\
\hline 7. Cerithiidae & Rhinoclavis sordidula & + & + & + & + & + \\
\hline 8. Chilodontidae & Euchelus asper & + & + & + & + & + \\
\hline \multirow{4}{*}{ 9. Conidae } & Conus amadis & + & + & - & - & - \\
\hline & Conus betulinus & + & + & + & + & + \\
\hline & Conus lentiginosus & + & + & + & + & + \\
\hline & Conus virgo & + & + & - & - & - \\
\hline 10. Fasciolariidae & Fusinus colus & + & + & + & + & + \\
\hline 11. Ficidae & Ficus variegata & + & + & + & + & - \\
\hline 12. Harpidae & Harpa major & + & + & + & + & + \\
\hline 13. Melongenidae & Pugilina conchlidium & + & + & + & + & + \\
\hline \multirow[t]{2}{*}{ 14. Muricidae } & Chicoreus virgineus & + & + & + & - & - \\
\hline & Murex carbonnieri & + & + & + & - & + \\
\hline \multirow[t]{3}{*}{ 15. Naticidae } & Eunaticina papilla & + & + & + & - & - \\
\hline & Natica lineata & + & + & - & - & - \\
\hline & Natica vitellus & + & + & + & + & + \\
\hline \multirow[t]{3}{*}{ 16. Olividae } & Agaronia nebulosa & + & + & - & - & - \\
\hline & Oliva caerulea & + & + & + & + & + \\
\hline & Oliva oliva & + & - & - & - & + \\
\hline 17. Potamididae & Telescopium telescopium & + & + & + & + & + \\
\hline 18. Strombidae & Strombus marginatus succinctus & + & + & + & + & + \\
\hline 19. Terebridae & Hastula inconstans & + & + & + & + & + \\
\hline 20. Tonnidae & Tonna cumingi & + & + & + & - & - \\
\hline 21. Trochidae & Umbonium vestiarium & + & + & - & - & - \\
\hline 22. Turbinellidae & Turbinella pyrum & + & + & - & - & + \\
\hline 23. Turridae & Gemmula unedo & + & + & + & + & + \\
\hline 24. Turritellidae & Turritella attenuata & + & + & - & - & - \\
\hline 25. Volutidae & Melo melo & + & + & + & + & + \\
\hline 26. Xenophoridae & Xenophora solariformis & + & + & - & - & - \\
\hline
\end{tabular}




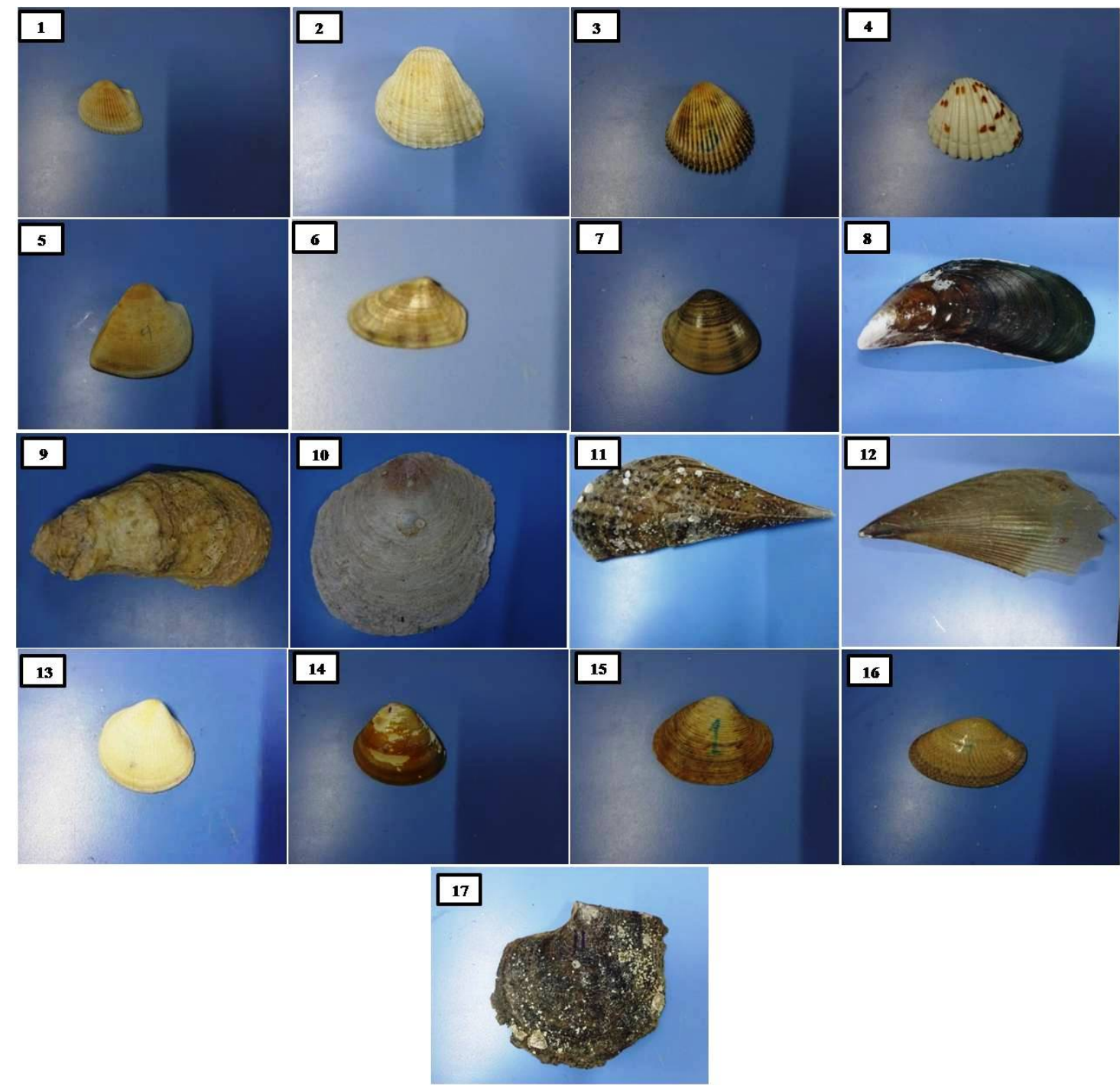

Figure 4: Distribution of Biavalve in Pulicat Lagoon. 
Table 2: List of gastropod identified from Pulicat Lagoon.

\begin{tabular}{|c|c|c|c|c|c|c|}
\hline Family & Name of the species & S1 & $\mathrm{S} 2$ & S3 & S4 & S5 \\
\hline \multirow[b]{2}{*}{ Arcidae } & Anadara antiquate & + & + & + & + & + \\
\hline & Anadara granosa & + & + & + & + & + \\
\hline Cardiidae & Vasticardium flavum flavum & + & + & - & - & - \\
\hline Carditidae & Cardita antiquata & + & + & + & - & + \\
\hline Cucullaeidae & Cucullaea labiata & + & + & + & + & - \\
\hline Donacidae & Donax cuneatus & + & + & + & + & + \\
\hline Mactridae & Mactra antiquata & + & + & + & + & + \\
\hline Mytilidae & Perna viridis & + & + & - & - & - \\
\hline Ostreidae & Crassostrea madrasensis & + & + & + & + & + \\
\hline Placunidae & Placuna placenta & + & + & - & - & - \\
\hline \multirow[t]{2}{*}{ Pinnidae } & Atrina (Atrina) vexillum & + & + & + & + & + \\
\hline & Pinna bicolor & + & + & - & - & - \\
\hline Tellinidae & Tellina cancellata & + & + & + & + & + \\
\hline \multirow[t]{3}{*}{ Veneridae } & Gafrarium tumidum & + & + & + & + & + \\
\hline & Paphia malabarica & + & + & + & + & + \\
\hline & Paphia textile & + & + & + & + & + \\
\hline Pteriidae & Pinctada margaritifera & + & + & - & - & - \\
\hline
\end{tabular}

Margalef index was minimum 1.329 during post monsoon 2014 at the Jameelabad (S5) and maximum 8.834 at monsoon 2014 were recorded in the Barmouth (S1) (Tab. 3). Margalef Diversity Index "Ma" has no limit value and it showed variation depending upon the number of species. Thus, it is used for comparison between the sites (Hazarika, 2013). The noticed value was 7.78 which was also at the inferior limit of the scale. Simson index was minimum 1.952 at the Jameelabad station (S5) in the time of post monsoon 2014 and maximum 27.118 at the Barmouth (S1) during the post monsoon 2015 was noticed (Tab. 3). Simpson index was closer to one pointed out almost acceptable diversity status of the Pulicat Lagoon. Shanon Wienerindex was minimum 1.040 in Jameelabad (S5) in the time of post monsoon 2014 and maximum 3.459 at Barmouth (S1) during the summer 2014 (Tab. 3). Diversity indices of mollusc's communities showed that Shannon index value $(\mathrm{H})$ was 0.50 , which was not at all satisfactory as " $\mathrm{H}$ " value above three indicating better balance and stable habitat condition (Mandaville, 2002). Pielou index "J" showed that molluscs species found minimum 0.580 at the Jameelabad (S5) during the post monsoon 2014 and maximum 0.971 during the monsoon 2014 at Sattankuppam (S4) (Tab. 3). Pielou index "J" showed that molluscs species reported area in the studied area almost evenly distributed because our calculated values were closer to one (Mandaville, 2002). 
Table 3: Molluscs fauna diversity indices of seasonal variations in 2013-2015.

\begin{tabular}{|c|c|c|c|c|c|c|}
\hline \multirow{2}{*}{$\begin{array}{l}\text { Study } \\
\text { period }\end{array}$} & \multirow[t]{2}{*}{ Seasons } & \multirow[t]{2}{*}{ Stations } & \multicolumn{4}{|c|}{ Diversity Indices } \\
\hline & & & $\begin{array}{l}\text { Margalef's } \\
\text { (M) }\end{array}$ & $\begin{array}{c}\text { Simpson's } \\
\text { (1/D) }\end{array}$ & $\begin{array}{c}\text { Shannon wiener } \\
(\mathrm{H})\end{array}$ & $\begin{array}{c}\text { Pielous's } \\
\text { index }\end{array}$ \\
\hline \multirow{5}{*}{2013} & \multirow{5}{*}{ Monsoon } & S1 & 8.834 & 23.297 & 3.406 & 0.875 \\
\hline & & S2 & 6.930 & 20.280 & 3.245 & 0.920 \\
\hline & & S3 & 4.013 & 7.538 & 2.436 & 0.879 \\
\hline & & S4 & 2.216 & 5.769 & 1.841 & 0.946 \\
\hline & & S5 & 1.747 & 3.396 & 1.536 & 0.790 \\
\hline \multirow{20}{*}{2014} & \multirow{5}{*}{$\begin{array}{c}\text { Post } \\
\text { monsoon }\end{array}$} & S1 & 7.112 & 26.793 & 3.438 & 0.914 \\
\hline & & S2 & 6.740 & 16.788 & 3.087 & 0.861 \\
\hline & & S3 & 3.852 & 12.651 & 2.700 & 0.917 \\
\hline & & $\mathrm{S} 4$ & 1.953 & 5.063 & 1.853 & 0.891 \\
\hline & & S5 & 1.329 & 1.952 & 1.040 & 0.580 \\
\hline & \multirow{5}{*}{ Summer } & S1 & 8.121 & 25.979 & 3.459 & 0.904 \\
\hline & & S2 & 7.062 & 18.862 & 3.186 & 0.904 \\
\hline & & S3 & 3.875 & 6.000 & 2.232 & 0.805 \\
\hline & & S4 & 1.846 & 4.091 & 1.587 & 0.886 \\
\hline & & S5 & 1.535 & 3.558 & 1.505 & 0.840 \\
\hline & \multirow{5}{*}{ Premonsoon } & S1 & 7.494 & 23.693 & 3.379 & 0.910 \\
\hline & & S2 & 5.868 & 13.674 & 2.906 & 0.882 \\
\hline & & S3 & 3.267 & 6.050 & 2.155 & 0.867 \\
\hline & & S4 & 2.164 & 5.333 & 1.787 & 0.918 \\
\hline & & S5 & 1.765 & 3.322 & 1.447 & 0.808 \\
\hline & \multirow{5}{*}{ Monsoon } & S1 & 6.795 & 26.049 & 3.409 & 0.924 \\
\hline & & S2 & 6.792 & 18.978 & 3.204 & 0.894 \\
\hline & & S3 & 4.973 & 13.984 & 2.901 & 0.913 \\
\hline & & S4 & 5.049 & 15.291 & 2.805 & 0.971 \\
\hline & & S5 & 4.010 & 11.700 & 2.676 & 0.909 \\
\hline \multirow{15}{*}{2015} & \multirow{5}{*}{$\begin{array}{c}\text { Post } \\
\text { monsoon }\end{array}$} & S1 & 6.937 & 27.118 & 3.448 & 0.917 \\
\hline & & S2 & 5.985 & 20.806 & 3.205 & 0.909 \\
\hline & & S3 & 5.016 & 18.250 & 3.061 & 0.940 \\
\hline & & S4 & 3.940 & 7.759 & 2.405 & 0.867 \\
\hline & & S5 & 3.168 & 7.496 & 2.327 & 0.859 \\
\hline & \multirow{5}{*}{ Summer } & S1 & 6.691 & 26.661 & 3.427 & 0.929 \\
\hline & & S2 & 6.123 & 21.486 & 3.232 & 0.909 \\
\hline & & S3 & 4.275 & 13.501 & 2.797 & 0.905 \\
\hline & & S4 & 3.244 & 8.426 & 2.369 & 0.898 \\
\hline & & S5 & 4.200 & 12.524 & 2.732 & 0.897 \\
\hline & \multirow{5}{*}{ Premonsoon } & S1 & 7.112 & 26.032 & 3.432 & 0.918 \\
\hline & & S2 & 5.932 & 18.441 & 3.142 & 0.907 \\
\hline & & S3 & 4.809 & 13.898 & 2.858 & 0.911 \\
\hline & & S4 & 3.478 & 11.025 & 2.510 & 0.951 \\
\hline & & S5 & 3.981 & 12.411 & 2.697 & 0.916 \\
\hline
\end{tabular}




\section{CONCLUSIONS}

The present investigation on molluscs species diversity associated with the lagoon ecosystems along Pulicat Lagoon, revealed the distribution of 34 gastropods and 17 bivalves, totalling to 51 molluscs species with one species of gastropod was dominant, namely C. madrasensis. It might, therefore, be useful and rewarding to further investigate the contributions of these macroinvertebrates towards nutrient processing and survey their role as biomonitors. 


\section{ACKNOWLEDGEMENTS}

The authors are thankful to Department of Science and Technology for providing financial assistance (RR. F. No. NRDMS/SC/ST/23/016 G). 


\section{REFERENCES}

1. Chacko P. I., Abraham J. G. and Andal R., 1953 - Report on survey of the Flora, Fauna and Fisheries of the Pulicat Lake, Madras state, India, 1951-1952, Contribution from the Fresh Water Fisheries Biological Station, Madras, 8, 21.

2. Govindan S., Ramanibai R. and Balakrishnan T., 2015 - Avifaunal diversity and status of Pulicat Lagoon in Tamil Nadu, India ZOO’s PRINT, 30, 24-27.

3. Hazarika P., 2013 - Diversity indices of macro invertebrates in the Satajan Wetland of Lakhimpur District, Assam Lakhi, Annals of Biological Research, 4, 8, 68-72.

4. Joshi S., Tambe P., Oak G. and Kurve P., 2013 - To study molluscan shells diversity of two fun beaches of Mumbai, Maharashtra, National Conference on Biodiversity: Status and Challenges in Conservation - FAVEO.

5. Khade S. N. and Mane U. H., 2012 - Diversity of Bivalve and Gastropod, Molluscs of some localities from Raigad District, Maharashtra, west coast of India, Recent Research in Science and Technology, 4, 10, 43-48.

6. Magurran A. E., 2003 - Measuring biological diversity, Blackwell, ISBN: 978-0-632-05633$0,264$.

7. Mandaville S. M. 2002 - Benthic macroinvertebrates in freshwaters, Taxa tolerance values, metrics, protocols, Project H-1, Soil and water conservation society of Metro Halifax, 18, 1-48.

8. Margalef R., 1958 - Information theory in ecology, General Systems, 3, 36-71.

9. Pawar P. R., 2012 - Moluscan diversity in mangrove ecosystem of Uran from Raigad Navi Mumbai, Maharashtra, West Coast of India, Bulletin of Environment, Pharmacology and Life Sciences, 1, 6, 55-59.

10. Pielou E. C., 1966 - The measurement of diversity in different types of biological collections, Journal of Theoretical Biology, 13, 131-144.

11. Richards C. S., 1970 - Genetics of a Molluscan Vector of Schistosomiasis, Nature, 227, 806810 .

12. Ramakrishna and Dey A., 2010 - Annotated Checklist of Indian Marine Molluscs (Cephalopoda, Bivalvia and Scaphopoda), Part-I, Records of the Zoological Survey of India, Occasional Paper, 320, 1-357.

13. Sanjeeva Raj P. J., 2003 - Strategies for conserving the macro fauna of Pulicat Lake - A case study. Natural Aquatic Ecosystems of India, Thematic Biodiversity Strategy and Action Plan, The National Biodiversity Action Plan, India, 228-238.

14. Sanjeeva Raj P. J., 2006 - Macro fauna of Pulicat Lake, NBA Bulletin, 6, National Biodiversity Authority, Chennai, Tamil Nadu, India, 67.

15. Subba Rao N. V., 2003 - Indian Seashells, I, Polyplacophora and Gastropoda, Edit. Director, Zoological Survey of India, 1-426.

16. Subba Rao N. V., 2003 - Indian Seashells, I, Polyplacophora and Gastropoda, Edit. Director, Zoological Survey of India, India, 1-426.

17. Supian Z. and Ikhwanuddin A. M., 2002 - Population dynamics of freshwater molluscs (Gastropod: Melanoidestuberculata), in Crocker Range Park, Sabah, ASEAN, Review of biodiversity and environmental conservation, ARBEC, 1-9.

18. Thangavelu R. and Sanjeeva Raj P. J., 1985 - Exploitation of shell-deposits in Pulicat Lake, Journal of the marine biological Association of India, 27 (1 and 2), 124-128.

19. Vannucci M., 2002 - Indo-west Pacific mangroves, in Lacerda L. D. (ed.), Mangrove ecosystems, Springer, Berlin, 122-215.

20. Venkataramanm K. M. and Wafar M. V. M., 2005 - Coastal and marine biodiversity of India, Indian Journal of Marine Science, 34, 1, 57-75

21. Venkatraman C. and Venkataraman K., 2012 - Diversity of Molluscan Fauna along the Chennai Coast, May 22nd International day for Biological Diversity Marine Biodiversity, 29-35.

22. Wosu L. O., 2003 - Commercial snail farming in West-Africa - A guide, ApExpess Publishers, NSukka-Nigeria. 